\title{
Review of moxifloxacin hydrochloride ophthalmic solution in the treatment of bacterial eye infections
}

\section{Darlene Miller}

Abrams Ocular Microbiology Laboratory, Bascom Palmer Eye Institute, Anne Bates Leach Eye Hospital, Miller School of MedicineUniversity of Miami, FL, USA
Correspondence: Darlene Miller Research Assistant Professor, Scientific Director, Abrams Ocular Microbiology Laboratory, Bascom Palmer Eye Institute, Anne Bates Leach Eye Hospital, Miller School of Medicine-University of Miami, 900 NW 17th Street, Miami, Florida 33136, USA

Tel +I 3053266034

Fax + I 305547366 I

Email dmiller@med.miami.edu

\begin{abstract}
Moxifloxacin hydrochloride ophthalmic solution $0.5 \%$ (Vigamox ${ }^{\circledR}$ ) is the ocular formulation/adaptation of moxifloxacin. Moxifloxacin is a broad spectrum 8-methoxyfluoroquinolone which terminates bacterial growth by binding to DNA gyrase (topoisomerase II) and topoisomerase IV, essential bacterial enzymes involved in the replication, translation, repair and recombination of deoxyribonucleic acid. Affinity for both enzymes improves potency and reduces the probability of selecting resistant bacterial subpopulations. Vigamox is a bactericidal, concentration dependent, anti-infective. It is preservative free, and well tolerated with minimal ocular side effects. It provides increased penetration into ocular tissues and fluids with improved activity against Streptococci and Staphylococci species and moderate to excellent activity against clinically relevant, gramnegative ocular pathogens.
\end{abstract}

Keywords: moxifloxacin, vigamox, pharmacodynamic indices, minimal inhibitory concentrations

\section{Introduction}

Moxifloxacin hydrochloride ophthalmic solution $0.5 \%$ is the ocular formulation/adaptation of moxifloxacin, an 8-methoxyfluoroquinolone, broad spectrum, anti-infective. It was introduced in 2003 as Vigamox ${ }^{\circledR}$ (Alcon Laboratories, Inc, Fort Worth, TX, USA) for the treatment of susceptible microorganisms recovered from patients with bacterial conjunctivitis. It is used more frequently off label for treatment of keratitis and as a prophylaxis agent in cataract and refractive surgeries (Vigamox 2004; Alfonso and Crider 2005; Schlech and Alfonso 2005).

It is an isotonic, preservative free, solution with a near neutral $\mathrm{pH}$ of 6.8 . The formula of Vigamox includes $5 \mathrm{mg} / \mathrm{mL}(0.5 \%)$ of moxifloxacin, boric acid, and purified water. Lack of the preservative BAK (benzalkonium chloride) makes it unique among current topical antibiotics licensed for use. Vigamox is currently available in more than 40 countries. Moxifloxacin hydrochloride ophthalmic solution $0.5 \%$, under the trade name Vegamox ${ }^{\circledR}$, was introduced into Japan in 2006, with approval for the treatment of bacterial conjunctivitis, keratitis and surgical prophylaxis.

\section{Chemistry}

Figure 1 shows the basic molecule and Figure 2 the moxifloxacin molecule. Table 1 shows the impact of core modifications.

\section{Moxifloxacin}

Moxifloxacin is a broad spectrum, 8-methoxy fluoroquinolone with improved activity against Streptococci and Staphylococci and moderate to excellent activity against clinically relevant, gram negative ocular pathogens (Smith et al 2001; Keating and Scott 2004). 


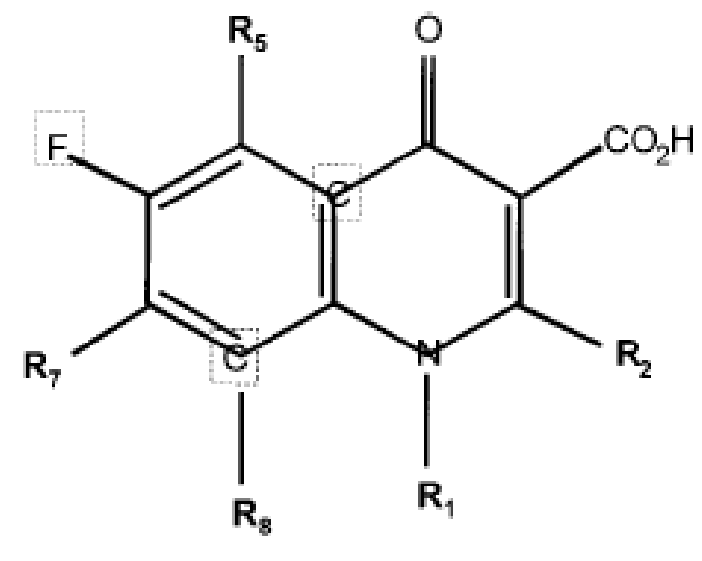

Figure I Basic 4-quinolone structure (adapted from Domagala 1994).

Modification of the parent molecule's core 4-quinolone core, at positions $1,5,7$, and 8 has engineered novel fluoroquinolones with enhanced antimicrobial activity, safety and tolerability (Keating and Scott 2004). Substitutions at the N-1 nitrogen atoms are critical for the spectrum of activity and potency of the molecule. The N-1 cyclopropyl substitution in moxifloxacin confers increased activity against gram-positive and anaerobic isolates. Substitutions at the C-5 position also impact the in vitro activity against gram-positive isolates; the larger the molecule the greater the gram positive potency. Addition of a bulky C-7 (diazabicyclononyl ring) side chain and a methoxy group at the $\mathrm{C}-8$ position reduces the potential for selection of resistant bacterial subpopulations and increase the binding/blocking affinity for DNA gyrase and topoisomerase IV, essential bacterial enzymes (Domagala 1994; Ball et al 1998; Appelbaum and Hunter 2000; Peterson 2001; Zhanel et al 2002; Caeiro and Iannini 2003; Saravolatz and Leggett 2003)

These modifications were incorporated to meet the challenge of emerging resistance in the older fluoroquinolones among ocular and nonocular isolates (Blondeau 1999; Chaudhry et al 1999; Goldstein et al 1999; Alexandrakis et al 2000; Zhanel and Noreddin 2001; Mather et al 2002; Hwang 2004; Mah 2004; Marangon et al 2004; Van Bambeke et al 2005).

\section{Mechanism of action}

Moxifloxacin is a bactericidal, concentration dependent, anti-infective. It interferes with bacterial survival by binding to DNA gyrase (topoisomerase II) and topoisomerase IV, essential bacterial enzymes involved in the replication, translation, repair and recombination of deoxyribonucleic acid. DNA gyrase is encoded by the genes gyra $\mathrm{A}$ and gyr B, while topoisomerase IV is encoded by Par C ( grl A) and pare (grl B). Inhibition of either enzyme leads to bacteria death (Zhanel and Noreddin 2001; Hwang 2004; Mah 2004; Van Bambeke et al 2005).

All fluoroquinolones bind to DNA gyrase and topoisomerase enzymes in susceptible organisms. The affinity or strength of the attachment varies; dependent on the class of fluoroquinolone and the bacteria species. Moxifloxacin binds strongly to both DNA gyrase and topoisomerase, but demonstrates preferential binding to DNA gyrase in gram-negative pathogens and Streptococcus pneumoniae. There is controversy as to the preferential target in the staphylococci. Preferential of dual targeting confirmation is dependent on methods used to evaluate the targets, and wild type strains employed to generate the mutants (Hooper 2001a; Oliphant and Green 2002; Ball et al 2004; Keating and Scott 2004).

Studies confirmed that for the older fluoroquinolones such as ciprofloxacin, topoisomerase IV is the preferred target in gram positive bacteria (Ball et al 1998; Dalhoff and Schmitz 2003; Drlica and Malik 2003; Zhanel et al 2006). In vitro studies supporting the dual activity of moxifloxacin have been mixed. Takei and colleagues using MIC ratios; classified moxifloxacin as a class three quinolone exhibiting dual activity against the two enzymes in Staphylococcus aureus (Takei,

Table I Impact of core modification and potency to the fluoroquinolones

\begin{tabular}{ll}
\hline Substitution area & Structure/side effects relationship \\
\hline RI & This area is part of the enzyme-DNA binding complex-inappropriate stereochemistry inhibits \\
& activity. A cyclopyl substitution here increases topoisomerase binding. \\
R2 & Area closes to the gyrase binding site: bulky side chains lowers potency \\
R3-R4 & These two groups interact with cleaved or damage DNA; no good substitutions/alternatives have \\
& been found \\
R-5 & Substitutions here affects topoisomerase affinity, $\mathrm{A} \mathrm{NH}_{2}$ or $\mathrm{CH}_{3}$ group adds gram-positive activity \\
R-6 & Affects potency; $\mathrm{NH}_{2}$ or $\mathrm{H}_{\text {possible, Interactions of }\left(\mathrm{R}^{2}+7+8\right) \text { are key }}$ \\
R-7 & Interacts with $\mathrm{DNA}$ gyrase. Bulky side chain here impedes efflux; increases gram positive activity \\
R-8 & Affects target affinity. $\mathrm{A} \mathrm{CH}_{3}$ or $\mathrm{OCH}_{3}$ increases affinity against anaerobes \\
\hline
\end{tabular}

Adapted from Domagala (1994), Peterson (2001). 


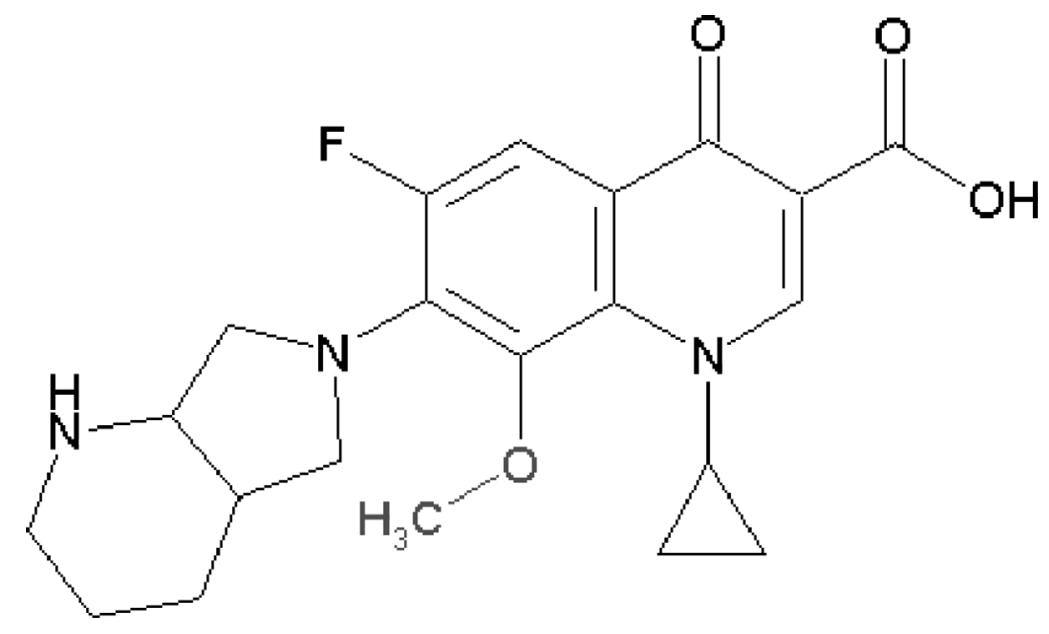

Figure 2 Moxifloxacin molecule..

Fukuda et al 2001). Topoisomerase IV was identified as the preferential target, with purified $S$. aureus DNA gyrase and topoisomerase IV enzymes by Ince and colleagues (Ince et al 2003). Griggs and co-workers (Griggs et al 2003) selected mutants with preferred affinity for DNA gyrase.

Exposure to fluoroquinolones may select single step mutants and or bacterial populations with increased tolerance or resistance. Mechanisms of resistance to the fluoroquinolones include subpopulations (mutants) with 1) mutations in DNA gyrase and or topoisomerase genes that alter/reduce the binding affinity of the enzymes, 2) gene mutations that block drug entry, 3) presence of an efflux pump that reduces drug accumulation and 4) unique genes that confer specific resistance against $S$. aureus (Zhanel et al 2002; Wise 2003; Mah 2004; Jacoby 2005; Van Bambeke et al 2005). Rare or emerging resistant mechanisms include 1) the presence of plasmids that protect cells from the lethal effects of the fluoroquinolones and 2) acquisition of a fluoroquinolone modifying enzyme (Robicsek et al 2006; Robicsek et al 2006).

Low level fluoroquinolone resistant populations usually contain a single mutation in DNA gyrase or topoisomerase IV. The preferred or primary target varies with the bacteria species and the fluoroquinolone. Key mutations usually occur in a unique region known as the quinolone resistant determining region (QRDR) of either DNA gyrase or topoisomerase IV. Secondary mutations may also occur in genes outside of these regions, in genes encoding efflux pumps, membrane permeability and cell transport. High level resistant isolates contain multiple gene mutations both in primary and in secondary targets. In areas with preexisting low levels of fluroquinolone resistance, exposure to suboptimal levels of the new fluoroquinolones will lead to rapid progression to double mutants and high level resistance (Hooper 2001b; Smith et al 2001; Zhanel et al 2002; Hwang 2004; Miller and Alfonso 2004).

Figure 3 highlights the evolution of fluoroquinolones resistance among ocular isolates recovered from postoperative endophthalmitis cases from one region (Miller et al 2006). At base line (1990-1994), low level resistance to ciprofloxacin $(10.3 \%)$ was evident, with no documented resistance to levofloxacin, gatifloxacin, or moxifloxacin. Emergence of multistep mutants or subpopulations resistant to levofloxacin and the 8 methoxy fluoroquinolones were steeper and almost 3 times higher compared to ciprofloxacin during the initialfive years following ciprofloxacin's introduction. Increasing resistance to ciprofloxacin and levofloxacin doubled in the last 5 years. Resistant populations increased by $8.9 \%$ for gatifloxacin and $5.1 \%$ for moxifloxacin during that same time period.

\section{Spectrum of activity}

In vitro studies comparing minimal inhibitory concentrations (MICs) from the United States, Asia and Europe have documented the in vitro efficacy of moxifloxacin against a broad array of ocular and nonocular pathogens (Blondeau 1999; Krasemann, Meyer et al 2001; Zhanel, Ennis et al 2002; Caeiro and Iannini 2003; Dalhoff and Schmitz 2003; Hwang 2004; Keating and Scott 2004; Mah 2004). Emerging trends indicate enhanced activity and excellent coverage for S. pneumoniae, Haemophilus influenzae, and methicillin susceptibile staphylococci compared to older fluoroquinolones. There was near equivocal coverage for Enterobacteriaceae, Pseudomonas aeruginosa, and other nonfermenters, but 

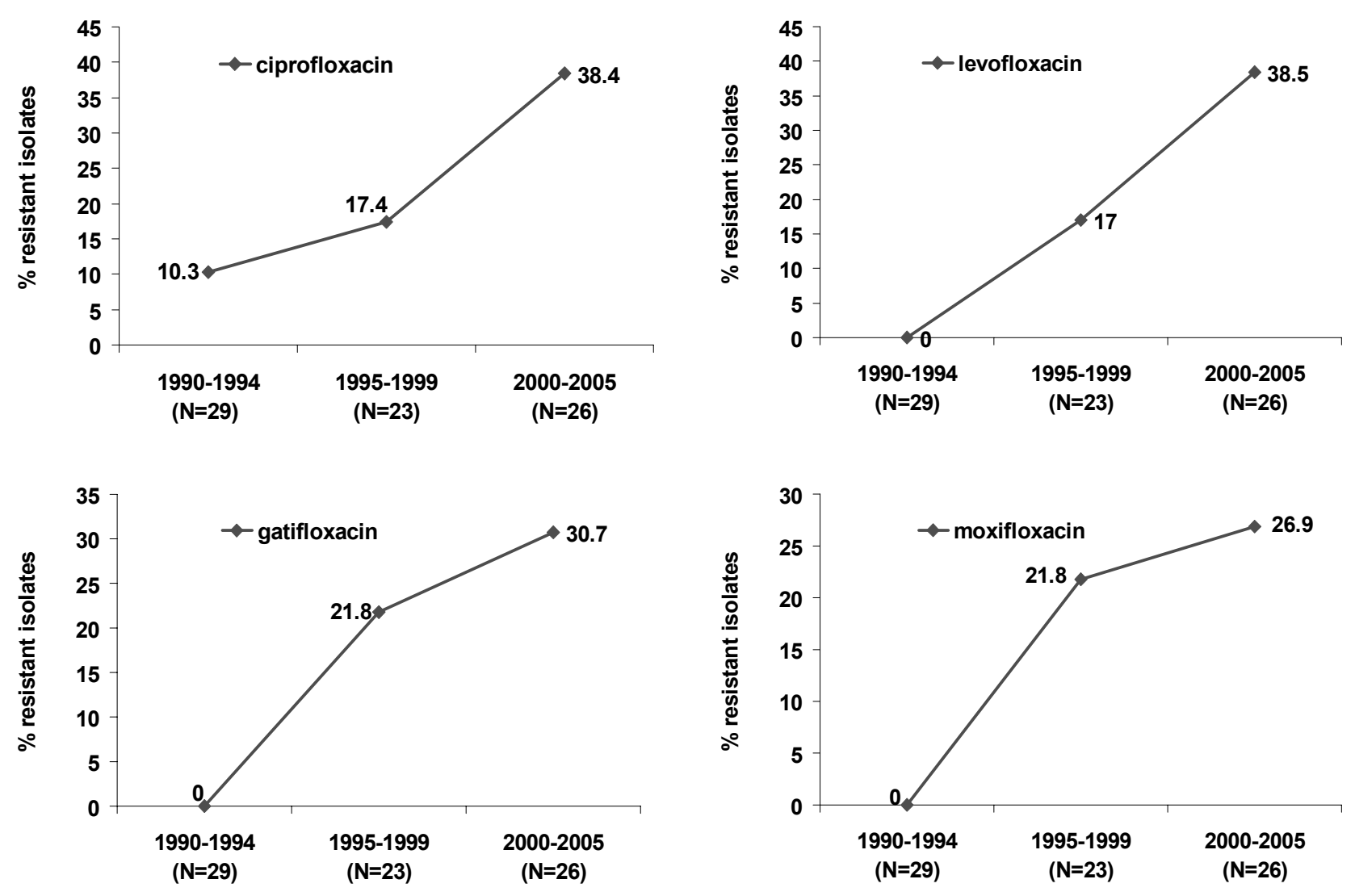

Figure 3 Evolution of fluoroquinolone resistance among coagulase negative staphylococci recovered from patients with post operative endophthalmitis ( $\mathrm{N}=78$ isolates) (derived from Miller and Flynn 2006).

suboptimal coverage for methicillin resistant staphylococci and enterococci, Table 2.

Greater than $10 \%$ resistance for moxifloxacin and or gatifloxacin was documented for several ocular pathogens, including S. pneumoniae (11.9\%), methicillin resistant S. aureus (95\% USA, 23.3\% Taiwan, methicillin resistant Staphylococcus epidermidis (69\% USA, 40\% Taiwan) and $P$. aeruginosa (18.3\% Taiwan).

Currently, there are few large, credible studies evaluating in vitro activity of moxifloxacin against new and older fluoroquinolones for common ocular pathogens. Many are hampered by low numbers of isolates (less than 30 per species), incomplete panel of challenge, comparative antibiotics or spectrum of pathogens and use conflicting or outdated interpretation standards.

Table 3 compares minimal inhibitory concentrations needed to inhibit $90 \%$ of pathogens $\left(\mathrm{MIC}_{90} \mathrm{~s}\right)$ for select ocular pathogens from North and South America for ciprofloxacin, gatifloxacin, and moxifloxacin. Results are impacted by methodology, isolate mix, testing period and interpretation standard applied. Minimal inhibitory concentrations against relevant ocular pathogens indicated that the 8-methoxy fluoroquinolones have improved efficacy against common ocular pathogens compared to ciprofloxacin. $\mathrm{MIC}_{90} \mathrm{~s}$ were 2-4 times lower for moxifloxacin versus ciprofloxacin and lower than or equivocal to gatifloxacin among important ocular pathogens. Percent susceptible ranged from 24\% (methicillin-resistant staphylococci) to $100 \%$ (S. pneumoniae) (Mather et al 2002; Kowalski et al 2003; Kowalski et al 2005; Stroman et al 2005; Oliveira et al 2007). Isolates resistant to ciprofloxacin were in general also resistant to moxifloxacin and gatifloxacin.

Resistance patterns to the fluoroquinolones vary by region, country, and ocular site. Studies comparing endemic background ciprofloxacin resistance demonstrated wide variation across regions in Europe, and North and South America (Table 4). Emerging resistant rates to moxifloxacin and gatifloxacin correlated with background ciprofloxacin resistant rates. Regions with the highest endemic resistance also reported the highest resistant rates to moxifloxacin and gatifloxacin (Mather et al 2002; Kowalski et al 2003; Kowalski et al 2005; Oliveira et al 2007) (Miller 2006, unpublished).

Other microbial pathogens considered susceptible to moxifloxacin include Chlamydia pneumoniae, Chlamydia 
Table 2 Comparative in vitro susceptibility of ciprofloxacin, gatifloxacin, and moxifloxacin against select nonocular pathogens

\begin{tabular}{|c|c|c|c|c|c|c|c|}
\hline \multirow[t]{2}{*}{ Country } & \multirow[t]{2}{*}{ Time period } & \multirow[t]{2}{*}{ Pathogen } & \multirow[t]{2}{*}{$\mathbf{N}$} & \multicolumn{3}{|l|}{ MIC $90 \mu \mathrm{g} / \mathrm{mL}$} & \multirow[t]{2}{*}{ Reference } \\
\hline & & & & Moxifloxacin & Gatifloxacin & Ciprofloxacin & \\
\hline \multirow[t]{10}{*}{ Canada } & Collected prior & & & & & & \\
\hline & to 1999 & & & & & & \\
\hline & & S. aureus & & & & & \\
\hline & & MSSA & 365 & $0.125(S)^{a}$ & $0.25(\mathrm{~S})$ & $\mathrm{ND}^{\mathrm{b}}$ & Blondeau et al 2000 \\
\hline & & MRSA & 42 & $2(\mathrm{R})$ & $4(\mathrm{R})$ & ND & \\
\hline & & S. pneumoniae & 399 & $0.25(\mathrm{~S})$ & $0.25-0.5(\mathrm{~S})$ & ND & \\
\hline & & H. influenzae & 199 & $0.063(S)$ & $0.016(S)$ & $0.031(S)$ & \\
\hline & & P. aeruginosa & 1472 & 16 & $8(\mathrm{R})$ & $4(\mathrm{R})$ & \\
\hline & & M. catarrhalis & 337 & $0.063(\mathrm{~S})$ & $0.031(S)$ & $0.031(S)$ & \\
\hline & & P. mirabilis & 30 & 0.5 & $0.25(\mathrm{~S})$ & $0.031(\mathrm{~S})$ & \\
\hline \multirow[t]{3}{*}{ USA } & |999-200| & S. pneumoniae & 3304 & $0.25(\mathrm{~S})$ & $0.5(S)$ & 2 & Jones et al 2003 \\
\hline & & H. influenzae & 3371 & $0.03(S)$ & $0.03(\mathrm{~S})$ & $0.03(S)$ & \\
\hline & & M. catarrhalis & 1656 & $0.06(S)$ & $0.03(\mathrm{~S})$ & $0.03(\mathrm{~S})$ & \\
\hline \multirow[t]{9}{*}{ USA } & April-December & MSSA & 34 & $0.06(\mathrm{~S})$ & & I (S) & Fass 1997 \\
\hline & 1996 & & & & & & \\
\hline & & MRSA & 20 & $4(\mathrm{R})$ & & $>32(\mathrm{R})$ & \\
\hline & & MSSE & 23 & 0.12 (S) & & $0.5(S)$ & \\
\hline & & MRSE & 29 & $2(\mathrm{R})$ & & $>32(\mathrm{R})$ & \\
\hline & & S. pneumoniae & 50 & $0.25(\mathrm{~S})$ & & I & \\
\hline & & H. influenzae & 45 & $0.03(S)$ & & $0.015(\mathrm{~S})$ & \\
\hline & & P. mirabilis & 33 & 2 & & $0.25(\mathrm{~S})$ & \\
\hline & & P. aeruginosa & 26 & $=32$ & & $\geq 32$ (R) & \\
\hline \multirow[t]{6}{*}{ Taiwan } & $1998-1999$ & MSSA & 58 & $0.06(\mathrm{~S})$ & & $0.5(S)$ & $\begin{array}{l}\text { Sheng Wang-Huei, } \\
\text { et al } 200 \text { I }\end{array}$ \\
\hline & & MRSA & 60 & $2(\mathrm{R})$ & & $16(\mathrm{R})$ & \\
\hline & & MSSE & 58 & $0.12(S)$ & & I (S) & \\
\hline & & MRSE & 60 & $8(\mathrm{R})$ & & $128(\mathrm{R})$ & \\
\hline & & S. pneumoniae & 42 & $4(\mathrm{R})$ & & 128 & \\
\hline & & P. aeruginosa & 60 & 2 & & $0.25(\mathrm{~S})$ & \\
\hline \multirow{13}{*}{$\begin{array}{l}\text { Europe (14), } \\
\text { Israel (I), } \\
\text { South America (3) }\end{array}$} & April 1997- & MSSA & 434 & $0.06(\mathrm{~S})$ & $0.12(\mathrm{~S})$ & $0.5(\mathrm{~S})$ & Milatovic et al 2000 \\
\hline & February 1999 & & & & & & \\
\hline & & & & & & & \\
\hline & & MRSA & 457 & $4(\mathrm{R})$ & $4(\mathrm{R})$ & $>16(\mathrm{R})$ & \\
\hline & & MSSE & 214 & $\mathrm{I}(\mathrm{I})$ & $2(\mathrm{R})$ & $16(\mathrm{R})$ & \\
\hline & & MRSE & 436 & $2(\mathrm{R})$ & $2(R)$ & $>16(\mathrm{R})$ & \\
\hline & & CoNS, other & 111 & $8(R)$ & $8(\mathrm{R})$ & $>16(\mathrm{R})$ & \\
\hline & & S. pneumoniae & 427 & $.25(\mathrm{~S})$ & $.5(\mathrm{~S})$ & 2 & \\
\hline & & S. viridans group & 97 & 0.25 & $0.5(S)$ & 4 & \\
\hline & & H. influenzae & 224 & $0.03(\mathrm{~S})$ & $.015(S)$ & $0.15(S)$ & \\
\hline & & P. aeruginosa & 615 & $>16$ & $>16$ & $>16(\mathrm{R})$ & \\
\hline & & P. mirabilis & 319 & 16 & $4(R)$ & $4(\mathrm{R})$ & \\
\hline & & S. marcescens & 211 & 4 & $2(S)$ & $2(I)$ & \\
\hline
\end{tabular}

aInterpretations were in accordance with the Clinical and Laboratory Standard Institute (CLSI) Performance for Antimicrobial Susceptibility Testing; Seventeenth Informational Informational Supplement. MI00-SI7. S, sensitive, I, intermediate, R, resistant.

${ }^{\mathrm{b}} \mathrm{ND}=$ not done. No CLSI standards for S. pneumoniae or S. viridans group and ciprofloxacin. No CLSI standards for gatifloxacin and moxifloxacin and P. aeruginosa. No CLSI standards for moxifloxacin S. marcescens, S. viridans group, and P. mirabilis.

Abbreviations: MIC $_{90}$, concentration that inhibits $90 \%$ of isolates tested; MSSA, methicillin sensitive Staphylococcus aureus; MRSA, methicillin resistant Staphylococcus aureus; MSSE, methicillin sensitive Staphylococcus epidermidis; MRSE, methicillin resistant Staphylococcus epidermidis; P. aeruginosa, Pseudomonas aeruginosa, M. catarrhalis, Moraxella catarrhalis; S. pneumoniae, Streptococcus pneumoniae; H. influenzae; Haemophilus influenzae; P. mirabilis, Proteus mirabilis; S. aureus, Staphylococcus aureus; S. viridans group; Streptococcus viridans group; CoNS other, coagulase negative staphylococci other than S. epidermidis; S. marcescens, Serratia marcescens.

trachomatis, Legionella pneumoniae and the some Mycobacteria species (Vigamox 2004).

Treatment of nontuberculosis with the 8-methoxyfluoroquinolones has been mixed. In a review of the early literature, Abshire and colleagues (Alcon Laboratories) offered data to support the use of moxifloxacin in the prevention and treatment on mycobacterial keratitis (Abshire et al 2004). Several case and series report successful treatment outcomes with the 8 methoxyfluoroquinolones as adjunctive therapy (Lee et al 2005; Chang and Welty 2006 p 272; John 
Table 3 Comparative $\mathrm{MIC}_{\mathbf{9 0}}$ s for moxifloxacin, gatifloxacin, and ciprofloxacin against select ocular pathogens

\begin{tabular}{|c|c|c|c|c|c|c|c|c|}
\hline & \multirow[t]{2}{*}{ Type } & \multirow[t]{2}{*}{ Ocular source } & \multicolumn{4}{|c|}{ Number MIC $90 \mu \mathrm{g} / \mathrm{mL}$} & \multirow[t]{2}{*}{ Time Period } & \multirow[t]{2}{*}{ Reference } \\
\hline & & & & Moxifloxacin & Gatifloxacin & Ciprofloxacin & & \\
\hline \multirow[t]{8}{*}{ S. aureus } & & Cornea & & & & & & \\
\hline & FQS & & 25 & $0.047(\mathrm{~S})^{\mathrm{a}}$ & $0.22(S)$ & $0.5(\mathrm{~S})$ & $1993-2003$ & Kowalski et al 2003 \\
\hline & $\mathrm{FQR}$ & & 25 & $4(\mathrm{R})$ & $12(\mathrm{R})$ & $128(\mathrm{R})$ & & \\
\hline & FQS & $\begin{array}{l}\text { Conjunctiva } \\
\text { isolates }\end{array}$ & 20 & $0.094(S)$ & $0.125(\mathrm{~S})$ & $0.5(S)$ & 1998-2002 & $\begin{array}{l}\text { Kowalski } \\
\text { et al } 2005\end{array}$ \\
\hline & $\mathrm{FQR}$ & & 20 & $6.0(\mathrm{R})$ & $64(\mathrm{R})$ & $>32(\mathrm{R})$ & & \\
\hline & NOS & All ocular & 21 & $0.25(\mathrm{~S})$ & $0.125(S)$ & $0.25(\mathrm{~S})$ & $2002-2004$ & $\begin{array}{l}\text { Oliveira } \\
\text { et al } 2007\end{array}$ \\
\hline & MSSA & All ocular & 53 & $\mathrm{I} .5(\mathrm{R})$ & $\mathrm{I} .5(\mathrm{R})$ & $32(R)$ & $200 I-2006$ & $\begin{array}{l}\text { Miller 2006, } \\
\text { unpublished }\end{array}$ \\
\hline & MRSA & & 39 & $32(\mathrm{R})$ & $32(\mathrm{R})$ & $32(\mathrm{R})$ & & \\
\hline $\begin{array}{l}\text { Coagulase } \\
\text { negative }\end{array}$ & & cornea & & & & & & \\
\hline \multirow[t]{5}{*}{ Staphylococci } & FQS & & & & & & & \\
\hline & & & 10 & $0.125(\mathrm{~S})$ & $0.19(S)$ & $0.3 / 8(S)$ & $1993-2002$ & $\begin{array}{l}\text { Kowalski } \\
\text { et al } 2003\end{array}$ \\
\hline & $\mathrm{FQR}$ & & 10 & $3(\mathrm{R})$ & $3(\mathrm{R})$ & $64(\mathrm{R})$ & & \\
\hline & FQS & $\begin{array}{l}\text { Intraocular } \\
\text { fluids }\end{array}$ & 10 & $0.05(S)$ & $0.09(S)$ & $0.13(\mathrm{~S})$ & $1993-2000$ & Mather et al 2002 \\
\hline & $\mathrm{FQR}$ & & 10 & $2.5(\mathrm{R})$ & $2(\mathrm{R})$ & $2.0(R)$ & & \\
\hline Coagulase & NOS & all ocular & 66 & $>32(\mathrm{R})$ & $>32(\mathrm{R})$ & $>32(\mathrm{R})$ & $200 I-2006$ & Miller 2006, \\
\hline Negative & & & & & & & & unpublished \\
\hline \multicolumn{9}{|l|}{ Staphylococci, } \\
\hline Coagulase & & All ocular & & & & & 2002-2004 & Oliveira \\
\hline Negative & & & & & & & & et al 2007 \\
\hline \multicolumn{9}{|l|}{ Staphylococci, } \\
\hline & FQS & & 57 & $0.75(\mathrm{I})$ & I (I) & $2(I)$ & & \\
\hline & $\mathrm{FQR}$ & & 21 & $3(\mathrm{R})$ & $2(\mathrm{R})$ & $>32(\mathrm{R})$ & & \\
\hline \multirow[t]{5}{*}{ S. pneumoniae } & & Cornea & 20 & $0.19(\mathrm{~S})$ & $0.25(S)$ & $2(I)$ & $1993-2002$ & Kowalski 2003 \\
\hline & & Conjunctiva & 20 & $0.09(\mathrm{~S})$ & $0.19(S)$ & $0.75(\mathrm{~S})$ & 1998-2002 & Kowalski 2005 \\
\hline & & Intraocular fluids & 10 & $0.09(S)$ & $0.22(S)$ & $0.75(\mathrm{~S})$ & $1993-2000$ & Mather et al 2002 \\
\hline & & All ocular & 20 & $0.19(S)$ & $0.19(S)$ & $3(\mathrm{R})$ & $200 I-2006$ & $\begin{array}{l}\text { Miller 2006, } \\
\text { unpublished }\end{array}$ \\
\hline & & All ocular & 16 & $0.12(S)$ & $0.19(S)$ & I (S) & $2002-2004$ & Oliveira et al 2007 \\
\hline \multirow[t]{3}{*}{ P. aeruginosa } & FQS & Cornea & 25 & 0.75 & 0.38 & $0.094(\mathrm{~S})$ & 1993-2002 & Kowalski et al 2003 \\
\hline & & All ocular & 40 & $>32$ & $>32$ & $>32(\mathrm{R})$ & $200 I-2006$ & $\begin{array}{l}\text { Miller 2006, } \\
\text { unpublished }\end{array}$ \\
\hline & & All ocular & 23 & 2 & I & $0.25(\mathrm{~S})$ & $2002-2004$ & Olivera et al 2007 \\
\hline \multirow[t]{3}{*}{ H. influenzae } & & Cornea & 10 & 0.19 (S0) & $0.06(S)$ & $0.03(\mathrm{~S})$ & $1993-2002$ & Kowalski et al 2003 \\
\hline & & Conjunctiva & 20 & $0.12(\mathrm{~S})$ & $0.25(S)$ & $1.0(S)$ & $1998-2002$ & Kowlaski et al 2005 \\
\hline & & All ocular & 21 & $0.5(\mathrm{~S})$ & $0.32(\mathrm{~S})$ & $0.19(\mathrm{~S})$ & $2002-2004$ & Oliveira et al 2007 \\
\hline
\end{tabular}

anterpretations were in accordance with the Clinical and Laboratory Standard Institute (CLSI) Performance for Antimicrobial Susceptibility Testing; Seventeenth Informational Informational Supplement. MI00-SI7. S, sensitive; I, intermediate; R, resistant.

${ }^{b}$ No CLSI standards for S. pneumoniae and ciprofloxacin. No CLSI standards for gatifloxacin and moxifloxacin and P. aeruginosa.

Abbreviations: MSSA, methicillin sensitive Staphylococcus aureus; MRSA, methicillin resistant Staphylococcus aureus; MIC $_{90}$, concentration that inhibits $90 \%$ of isolates tested; FQS, fluoroquinolone sensitive; FQR, fluroquinolone resistant; NOS, Staphylococcus aureus, not otherwise specified or Coagulase negative staphylococci not otherwise specified.

and Velotta 2005 p 461). Others have reported therapeutic failures with these drugs (Hofling-Lima et al 2005; Moshirfar et al 2007).

The majority of the mycobacterial keratitis cases have been reported following outbreaks (Freitaset al 2003; Karp et al 2003; Winthrop et al 2003; John and Velotta 2005). Increased awareness, control measures and modified surgical techniques have reduced the frequencies of mycobacterial infections in the United States. The current recommendation for treatment of mycobacterial keratitis is alternative treatment with amikacin and one of the 8-methoxyfluoroquinolones (Donnenfeld et al 2005).

Case reports and series from other ocular sites have been rare (Gupta et al 2003; Wilhelmus 2003; Nielsen et al 2004; 
Table 4 Regional and geographic variation in endemic fluoroquinolone resistance (\%) among ocular pathogens

\begin{tabular}{|c|c|c|c|c|c|c|}
\hline \multirow[t]{2}{*}{ Region } & \multicolumn{5}{|c|}{ Fluoroquinolone } & \multirow[t]{2}{*}{ Reference } \\
\hline & Ciprofloxacin & Gatifloxacin & Moxifloxacin & Number of Isolates & Time Period & \\
\hline Europe & 12.4 & 5.5 & ND & 532 & July 200 I-Dec 2002 & Morrissey et al 2004 \\
\hline France & 12.4 & 5.6 & ND & & & \\
\hline Germany & 4.6 & 1.5 & ND & & & \\
\hline Italy & 19.9 & 4.6 & ND & & & \\
\hline Spain & 15.9 & 9.8 & ND & & & \\
\hline Sweden & 2.0 & 0 & ND & & & \\
\hline UK & 8.3 & 8.3 & ND & & & \\
\hline USA (Northeast) & 28.3 & 13.7 & 20 & 350 & $1993-2005$ & $\begin{array}{l}\text { Mather et al 2002; } \\
\text { Kowlaski et al 2003; } \\
\text { Kowalski et al } 2005\end{array}$ \\
\hline USA (South Florida) & 30.1 & 16.7 & 23.3 & 431 & $2000-2006$ & Miller 2006 (unpublished) \\
\hline Brazil & 14.2 & 11.9 & 11.9 & 183 & $2002-2004$ & Oliveira et al 2007 \\
\hline
\end{tabular}

$\mathrm{ND}=$ Not done.

Spencer et al 2005; Matieli et al 2006). Treatment strategies include amikacin and clarithromycin (Wilhelmus 2003).

The antifungal activities of the 8-methoxyfluoroquinolones have been investigated. There is both in vitro and in vivo evidence for some efficacy of the 8 methoyl fluoroquinolones to reduce fungal loads in the lab and for patients with contact lens associated fungal keratitis. Additional studies need to be done (Ozdek et al 2006; Munir et al 2007)

\section{Pharmacokinetics}

Direct application of topical antimicrobial to conjunctival and corneal tissues can initially provide very high local and aqueous chamber concentrations. Final or sustained concentrations are altered by rapid tear film dissipation, underlying tissue health and dosing frequency (Robertson et al 2005; Stroman et al 2005).

Penetration of moxifoxacin has been studied in ocular tissues and fluids in both humans and animals. Human studies have revealed wide variation in drug concentrations. Recorded concentrations are impacted by route of administration, dosing frequency, site of infection, presence or absence of epithelial defect and underlying disease. The recommended dosing frequency for the treatment of bacterial conjunctivitis is one drop 3 times a day for 5 days. (Vigamox 2004; Alfonso and Crider 2005; Robertson et al 2005; Stroman et al 2005)

In general, moxifloxacin's high concentration formulation, enhanced bioavailability, and solubility have allowed for levels 2- to 4-fold higher ocular tissues levels than gatifloxacin $\left(Z_{y m a r}{ }^{\circledR}\right.$, Allergan, Irvine CA), ciprofloxacin (Ciloxacin $^{\circledR}$, Alcon, Ft. Worth, TX), levofloxacin (Quixin ${ }^{\circledR}$, Vistakon Pharmaceuticals, USA), or ofloxacin (Ocuflox ${ }^{\circledR}$, Allergan, Irvine, CA) (Cekic et al 1999a; Cekic et al 1999b;
Garcia-Saenz et al 2001; Smith et al 2001; Donnenfeld et al 2004; Hwang 2004; Mah 2004; Koch et al 2005; Robertson et al 2005; Chang Lin and Welty 2006; O'Brien 2006)

Table 5 summarizes studies evaluating the penetration of moxifloxacin, gatifloxacin and ciprofloxacin into the aqueous and vitreous chambers by topical and oral routes of administration. Topical dosing protocols that mimic pre and post dosing frequencies for cataract and refractive surgeries of 4 times a day, pulsing dosing or a combination of the two, report concentration levels in the aqueous chamber that ranged from $0.38 \pm 0.32 \mu \mathrm{g} / \mathrm{mL}$ to $2.28 \pm 1.23 \mu \mathrm{g} / \mathrm{mL}$.

Resultant concentration in the vitreous ranged from $0.011 \pm 0.008 \mu \mathrm{g} / \mathrm{mL}$ to $0.11 \pm 0.05 \mu \mathrm{g} / \mathrm{mL}$. Vitreal concentrations were 20- to 40-fold lower than those obtained in the aqueous. (Donnenfeld et al 2004; Hariprasad et al 2005; Hariprasad et al 2005; Katz et al 2005; Kim et al 2005a; Kim et al 2005b; Solomon et al 2005; Costello et al 2006; McCulley et al 2006; Ong-Tone 2007). Concentration levels in the aqueous and the vitreous were usually 2-fold higher for moxifloxacin compared to gatifoxacin or ciloxacin.

Oral administration of 400-800 $\mathrm{mg}$ of moxifloxacin ranged from $0.21 \pm 0.21 \mu \mathrm{g} / \mathrm{mL}$ to $2.33 \mu \mathrm{g} / \mathrm{mL} \pm 0.85$ and produced concentrations that were comparable to topical administration in the aqueous chamber. Drug levels were negligible in the vitreous (Garcia-Saenz et al 2001; Kampougeris et al 2005; Hariprasad et al 2006; Vedantham et al 2006; Fuller et al 2007; Walter et al 2007).

\section{Pharmacodynamics}

The therapeutic success or potency of an antibacterial agent is a complex interrelationship between drug and its ability to reach the target site (pharmacokinetics), the microbial pathogen and susceptibility to the selective drug 
Table 5 Penetration studies of moxifloxacin and comparators into aqueous and vitreous humor

\begin{tabular}{|c|c|c|c|c|c|c|c|c|c|}
\hline \multirow{2}{*}{$\begin{array}{l}\text { Route of } \\
\text { Administration }\end{array}$} & \multirow[t]{2}{*}{ Dosing } & \multirow[t]{2}{*}{ Dosage } & \multicolumn{2}{|c|}{ Moxifloxacin } & \multicolumn{2}{|c|}{ Gatifloxacin } & \multicolumn{2}{|c|}{ Ciprofloxacin } & \multirow[t]{2}{*}{ Reference } \\
\hline & & & $\begin{array}{l}\text { Aqueous } \\
(\mu \mathrm{g} / \mathrm{mL})\end{array}$ & $\begin{array}{l}\text { Vitreous } \\
\text { ( } \mu \mathrm{g} / \mathrm{mL})\end{array}$ & $\begin{array}{l}\text { Aqueous } \\
(\mu \mathrm{g} / \mathrm{mL})\end{array}$ & $\begin{array}{l}\text { Vitreous } \\
(\mu g / m L)\end{array}$ & $\begin{array}{l}\text { Aqueous } \\
(\mu \mathrm{g} / \mathrm{mL})\end{array}$ & $\begin{array}{l}\text { Vitreous } \\
(\mu \mathrm{g} / \mathrm{mL})\end{array}$ & \\
\hline \multirow[t]{15}{*}{ Topical } & $\begin{array}{l}\text { I drop } / 2 \text { hours } \times 3 \\
\text { days }\end{array}$ & $\begin{array}{l}43 \\
\text { drops }\end{array}$ & $\begin{array}{l}2.28 \pm \\
1.23\end{array}$ & $\begin{array}{l}0.11 \pm \\
0.05\end{array}$ & ND & ND & ND & ND & $\begin{array}{l}\text { Hariprasad } \\
\text { et al } 2005\end{array}$ \\
\hline & $\begin{array}{l}\text { I drop/6 hours } \times \\
3 \text { days }\end{array}$ & 22 & $\begin{array}{l}0.88 \pm \\
0.88\end{array}$ & $\begin{array}{l}0.06 \pm \\
0.06\end{array}$ & ND & ND & ND & ND & $\begin{array}{l}\text { Hariprasad } \\
\text { et al } 2005\end{array}$ \\
\hline & $\begin{array}{l}\text { I drop/10 min } \\
\text { prior to surgery }\end{array}$ & 4 drops & $\begin{array}{l}1.80 \pm \\
1.25\end{array}$ & & $\begin{array}{l}0.48 \pm \\
0.34\end{array}$ & & & & $\begin{array}{l}\text { Kim et al } \\
2005\end{array}$ \\
\hline & $4 \times /$ day $\times 3$ days & 15 & $1.31 \pm$ & & $0.63 \pm$ & & $0.15 \pm$ & & Solomon \\
\hline & $\begin{array}{l}\text { plus } 3 \text { drops } \\
\text { I hour prior to } \\
\text { surgery }\end{array}$ & drops & 0.46 & & 0.30 & & 0.11 & & et al 2005 \\
\hline & 4 times/day & 5 drops & $1.86 \pm$ & & $0.94 \pm$ & & & & McCulley \\
\hline & $\begin{array}{l}\text { I day prior and } \\
\text { I drop prior to } \\
\text { surgery }\end{array}$ & & 0.23 & & 0.15 & & & & et al 2006 \\
\hline & $\begin{array}{l}4 \text { drops pre } \\
\text { surgery }\end{array}$ & 4 drops & $\begin{array}{l}1.55 \pm \\
0.86\end{array}$ & & $\begin{array}{l}0.74 \pm \\
0.66\end{array}$ & & & & $\begin{array}{l}\text { Katz et al } \\
2005\end{array}$ \\
\hline & $\begin{array}{l}4 \text { times a day/I } \\
\text { day before and } \\
4 \text { drops, pre } \\
\text { surgery }\end{array}$ & 4 drops & $\begin{array}{l}1.61 \pm \\
0.71\end{array}$ & & $\begin{array}{l}0.91 \pm \\
0.54\end{array}$ & & & & \\
\hline & $\begin{array}{l}4 \times 2 \text { days pre } \\
\text { op }\end{array}$ & 8 drops & $\begin{array}{l}0.38 \pm \\
0.32\end{array}$ & & $\begin{array}{l}0.19 \pm \\
0.23\end{array}$ & & & & $\begin{array}{l}\text { Ong-Tone } \\
\text { et al } 2007\end{array}$ \\
\hline & $4 \times 2$ days pre & 11 & $2.16 \pm$ & & $0.82 \pm$ & & & & \\
\hline & op plus 3 drops & drops & 1.12 & & 0.31 & & & & \\
\hline & $\begin{array}{l}2 \text { hours prior to } \\
\text { surgery }\end{array}$ & & & & & & & & \\
\hline & $4 \times 3$ days & 12 & & $0.011 \pm$ & & $0.008 \pm$ & & & Costello et al \\
\hline & before surgery & drops & & 0.008 & & 0.006 & & & 2006 \\
\hline \multirow[t]{8}{*}{ Oral } & 2 tablets $(400 \mathrm{mg})$ & $800 \mathrm{mg}$ & & $1.55 \pm$ & & & & & Fuller et al \\
\hline & $\begin{array}{l}\text { at I } 4 \text { and } 3 \text { hours } \\
\text { before surgery }\end{array}$ & & & 0.33 & & & & & 2006 \\
\hline & $\begin{array}{l}2 \text { tablets, evening } \\
\text { prior to surgery } \\
\text { and } 3 \text { hours } \\
\text { before surgery }\end{array}$ & $800 \mathrm{mg}$ & $\begin{array}{l}1.34 \pm \\
0.66\end{array}$ & $\begin{array}{l}1.58 \pm \\
0.80\end{array}$ & & & & & $\begin{array}{l}\text { Hariprasad } \\
\text { et al } 2006\end{array}$ \\
\hline & $\begin{array}{l}\text { Single tablet } \\
\text { I-2 hours before } \\
\text { surgery }\end{array}$ & $400 \mathrm{mg}$ & $\begin{array}{l}0.21 \pm \\
0.21\end{array}$ & $\begin{array}{l}0.09 \pm \\
0.09\end{array}$ & & & & & $\begin{array}{l}\text { Vedantham } \\
\text { et al } 2005\end{array}$ \\
\hline & $\begin{array}{l}\text { Single tablet, } \\
\text { I0 hours before } \\
\text { surgery }\end{array}$ & $400 \mathrm{mg}$ & $\begin{array}{l}2.33 \pm \\
0.85\end{array}$ & & & & & & $\begin{array}{l}\text { Garcia- } \\
\text { Saenz et al } \\
2001\end{array}$ \\
\hline & Single dose & $400 \mathrm{mg}$ & $1.17 \pm$ & & & & & & Walter et al \\
\hline & Prior to surgery & & $\begin{array}{l}0.40(10 \\
\text { hours })\end{array}$ & & & & & & 2007 \\
\hline & $\begin{array}{l}2 \text { tablets, } 12 \\
\text { hours apart }\end{array}$ & $400 \mathrm{mg}$ & $\begin{array}{l}1.23 \pm \\
0.55(12 \\
\text { hours) }\end{array}$ & & & & & & $\begin{array}{l}\text { Kampougeris } \\
\text { et al } 2007\end{array}$ \\
\hline
\end{tabular}

(pharmacodynamics), and the underlying immune status of the patient (Figure 4).

Pharmacokinetics is the dispersion and metabolism of the drug in the body. It is defined by the absorption, distribution, dosage and protein binding characteristics of the drug, which may vary among individual drugs in a class. Pharmacodynamics defines the impact of the antimicrobial agent on the infecting microorganism. It is characterized by the bacterial species, mechanism of microbial resistance, growth phase, infecting inoculum, degree of kill, time kill 


\section{Antimicrobial}

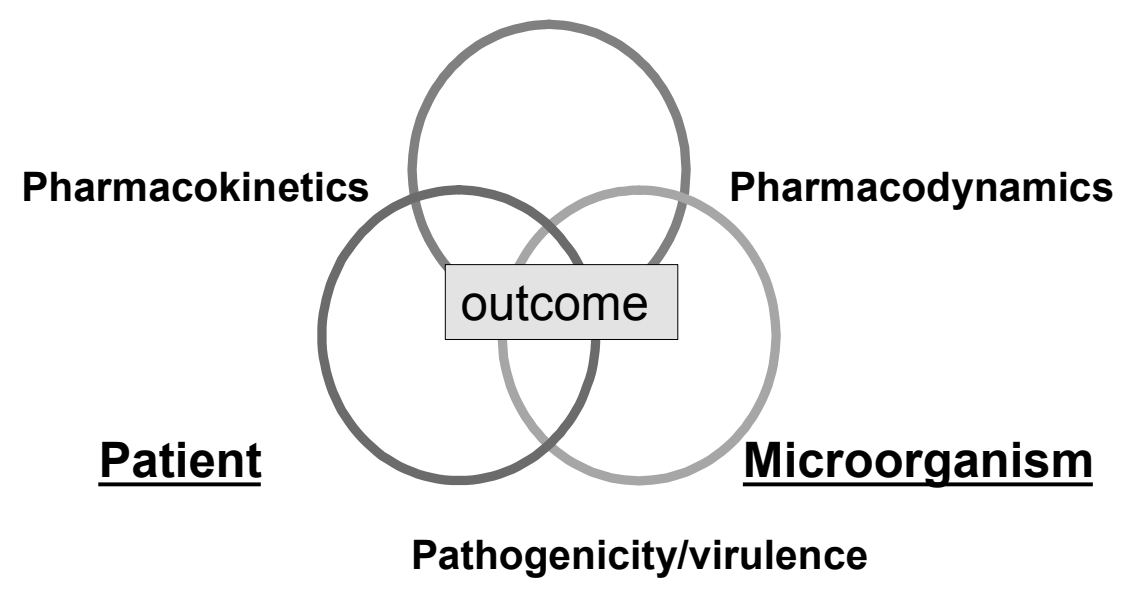

Figure 4 Factors affecting favorable outcomes during antimicrobial therapy.

and MIC distribution. The third partner in this complex relationship is what both the drug and the pathogen do to the patient. This interplay is described by the patient's age, genetic background, underlying disease and prior antimicrobial exposure.

The ratio of peak concentration $\left(\mathrm{C}_{\max }\right)$ to the MIC and the area under the concentration curve (AUC) are the pharmacodynamic indices that correlate most favorable with clinical outcomes for concentration-dependent anti-infectives. Maintaining adequate concentration of an antibiotic above a certain level known as the mutant prevention concentration (MPC) can also reduce the probability of selecting resistant subpopulations and increasing a favorable clinical outcome.

Antibiotic penetration into ocular tissues and fluids must not only reach but exceed the minimal inhibitory concentration (MIC) sufficiently to meet the targeted pharmacodynamic indices $\left(\mathrm{C}_{\max }:\right.$ MIC or MPC) by a factor of 10. $\mathrm{A} \mathrm{C}_{\max }$ :MIC ratio or MPC values greater than 10 have been documented to eradicate pathogens and suppress emergence of resistance in patients treated with fluoroquinolones (Allen et al 2004; Metzler et al 2004; Smith et al 2004; Hermsen et al 2005).

Wilhelmus (Wilhelmus 2003; Wilhelmus et al 2003) confirmed the application and utility of pharmacodynamic indices to predict clinical outcome in patients with bacterial keratitis. The pharmacodynamic indices (PDI): $\mathrm{C}_{\max }: \mathrm{MIC}$ and AUC:MIC were use to correlate clinical outcome for 391 patients with bacterial keratitis. Clinical improvement was associated with a $\mathrm{C}_{\max }$ :MIC ratio greater than 8 and an AUC:MIC ratio greater than 152. Corneal pathogens included S. aureus (21\%), P. aeruginosa (12\%), S. pneumoniae (7\%),
Streptococcus viridans (5\%), other gram-positive isolates (44\%), and other gram-negative isolates (11\%).

Table 6 displays calculated pharmacodynamic indices (PDI) for moxifloxacin and gatifloxacin using reported aqueous concentrations and $\mathrm{MIC}_{50} \mathrm{~s} / \mathrm{MIC}_{90} \mathrm{~s}$ values for coagulase negative staphylococci recovered from endophthalmitis (Mather et al 2002; Miller et al 2006)

Targeted PDIs ranged from less than or equal to 0.038 $\mu \mathrm{g} / \mathrm{mL}$ to $0.228 \mu \mathrm{g} / \mathrm{mL}$ for moxifloxacin and less than or equal to $0.048-0.094 \mu \mathrm{g} / \mathrm{mL}$ for gatifloxacin. Obtainable moxifloxacin concentrations exceeded the MIC and met the PDI factor of 10 for $89 \%(8 / 9)$ and $78 \%$ (7/9) of the isolates when using the $\mathrm{MIC}_{50}$. None of the moxifloxacin concentrations were sufficient to provide coverage for fluoroquinolone resistant coagulase negative staphylococci for reported $\mathrm{MIC}_{90} \mathrm{~s}$.

Gatifloxacin concentrations met the PDI factor of 10 for $28 \%(2 / 7)$ of the isolates at the $\mathrm{MIC}_{50}$ value of $0.09 \mu \mathrm{g} / \mathrm{mL}$. None of the obtainable Zymar concentrations met the PDI factor of 10 for fluoroquinolone resistant isolates at values reported by Miller et al (2006).

In a more recent report from the same Institution, Harper and colleagues (Harper et al 2007) confirmed the low peak concentration:mic ratios for both gatifloxacin and moxifloxacin using reported intraocular levels against 59 coagulase negative staphylococci isolates collected between 1993 and 2006. Moxifloxacin ratios $\left(\mathrm{C}_{\max }: \mathrm{MIC}_{90}\right)$ were higher than gatifloxacin $(0.05 \mu \mathrm{g} / \mathrm{mL}$ vs $0.02 \mu \mathrm{g} / \mathrm{mL})$ but lower than vancomycin $(0.45 \mu \mathrm{g} / \mathrm{mL})$ for reported mean $(1.66 \mu \mathrm{g} / \mathrm{mL})$ aqueous concentrations. A significant difference in the PDI parameter was observed for moxifloxacin when the $\mathrm{MIC}_{50}$ 
Table 6 Comparative $\mathrm{MIC}_{50} \mathrm{~s}, \mathrm{MIC}_{90} \mathrm{~s}$, and calculated pharmacodynamic indices for moxifloxacin and gatifloxacin for coagulasenegative staphylococci versus reported aqueous concentrations

\begin{tabular}{|c|c|c|c|c|c|c|}
\hline Drug & Source & $\mathbf{C}_{\max }$ & $\begin{array}{l}\text { Calculated } \\
\text { MIC/MPC } \\
\text { target value }\end{array}$ & $\mathrm{MIC}_{50}$ & $\mathrm{MIC}_{50}$ & $\mathrm{MIC}_{90}$ \\
\hline & & & & (Mather et al 2002) & (Miller et al 2006) & \\
\hline \multirow[t]{9}{*}{ Moxifloxacin } & Aqueous & $0.38 \pm 0.32$ & $\leq 0.038$ & 0.05 (FQS) 2.5 (FQR) & 0.09 & 4 \\
\hline & & $0.88 \pm 0.88$ & $\leq 0.088$ & & & \\
\hline & & $\mathrm{I} .3 \mathrm{I} \pm 0.46$ & $\leq 0.131$ & & & \\
\hline & & $1.55 \pm 0.86$ & $\leq 0.155$ & & & \\
\hline & & $1.6 \mathrm{I} \pm 0.7 \mathrm{I}$ & $\leq 0.161$ & & & \\
\hline & & $1.80 \pm 1.25$ & $\leq 0.180$ & & & \\
\hline & & $1.86 \pm 0.23$ & $\leq 0.186$ & & & \\
\hline & & $2.16 \pm 1.12$ & $\leq 0.216$ & & & \\
\hline & & $2.28 \pm 1.23$ & $\leq 0.228$ & & & \\
\hline \multirow[t]{7}{*}{ Gatifloxacin } & Aqueous & $0.19 \pm 0.23$ & $\leq 0.019$ & 0.09 (FQS) 2.0 (FQR) & 0.19 & 4 \\
\hline & & $0.48 \pm 0.34$ & $\leq 0.048$ & & & \\
\hline & & $0.63 \pm 0.30$ & $\leq 0.063$ & & & \\
\hline & & $0.74 \pm 0.66$ & $\leq 0.074$ & & & \\
\hline & & $0.82 \pm 0.31$ & $\leq 0.082$ & & & \\
\hline & & $0.91 \pm 0.54$ & $\leq 0.091$ & & & \\
\hline & & $0.94 \pm 0.15$ & $\leq 0.094$ & & & \\
\hline
\end{tabular}

Derived from Mather et al (2002), Miller and Flynn (2006).

Abbreviations: $\mathrm{MIC}_{90}$, concentration that inhibits $90 \%$ of isolates tested; $\mathrm{MIC}_{50}$, concentration that inhibits $50 \%$ of isolates tested; $\mathrm{FQS}$, fluoroquinolone sensitive; FQR, fluroquinolone resistant.

rather than the $\mathrm{MIC}_{90}$ was used. The ratio for moxifloxacin using the $\mathrm{MIC}_{50}$ was $2.2 \mu \mathrm{g} / \mathrm{mL}$ vs $0.83 \mu \mathrm{g} / \mathrm{mL}$ for gatifloxacin and $0.67 \mu \mathrm{g} / \mathrm{mL}$ for vancomycin.

\section{Clinical efficacy}

No clinical trials have been conducted evaluating moxifloxacin vs. nonfluroquinolone antibiotics for the treatment of keratitis and or endophthalmitis. In two pre-marketing, randomized, double-masked, multi-centered, controlled clinical trials to assess, safety and efficacy of moxifloxacin for the treatment of bacterial conjunctivitis, clinical cures were documented in $66 \%-69 \%$ of patients by day 4 . Microbiological eradication occurred in $84 \%-94 \%$ of the patients. Patients were dosed 3 times a day for 4 days. Age groups ranged from 2 to 92 . No adverse events were reported in this group (Alfonso and Crider 2005).

Deramo and colleagues reported no significant difference in the rate of endophthalmitis using 4 times a day dosing of moxifloxacin or gatifloxacin pre- and post-operative compared to established endophthalmitis infection rates. In a retrospective, multicentered review of 20,013 patients from 9 cataract centers across 7 states, the overall rate of endophthalmitis following cataract surgery was $0.07 \%$. The rate of postoperative endophthalmitis in the gatifloxacintreated group $(81 \%, 16,209)$ was $0.06 \%$ ( 9 cases) and the rate for the moxifloxacin-treated group $(19 \%, 3804)$ was
$0.1 \%$ ( 5 cases). The difference was not significant ( $p=0.11$, nor was this rate lower than the earlier study by Miller et al using clear corneal phacoemulsification (Miller et al 2005; Deramo et al 2006).

\section{Safety and biocompatibility}

Reported adverse reactions with $0.5 \%$ moxifloxacin hydrochloride ophthalmic solution administration have included: conjunctivitis, keratitis, decreased visual acuity, ocular hyperemia, dry eye, itching, subconjunctival hemorrhage, and tearing (Alcon Laboratories package insert) (Hariprasad et al 2005). Other infrequent ocular adverse events reported for the fluoroquinolones as a class include chemosis, eyelid edema, and punctuate epithelial keratitis (Mah 2004).

In vitro and animals studies have demonstrated a concentration dependent toxicity in studies of corneal epithelial cell migration and or proliferation, key components in corneal wound healing (Mallari et al 2001; Donnenfeld et al 2004; Kovoor et al 2004; Burka et al 2005; Durrie and Trattler 2005; McGee et al 2005; Robertson et al 2005; Solomon et al 2005; Donaldson et al 2006; Kaufman et al 2006; Ly et al 2006; Matsumoto et al 2006; McDermott and Wheater 2006; Stern et al 2006; Walter and Tyler 2006).

Matsumoto and colleagues reported low and equivocal cell migration inhibition scores for moxifloxacin and gatifloxacin versus ciprofloxacin at low concentrations 
$(<0.4 \mathrm{mmol} / \mathrm{L})$, but greater toxicity for moxifloxacin and ciprofloxacin versus gatifloxacin at higher concentrations ( $\geq 0.64 \mathrm{mmol} / \mathrm{L}$ ) (Matsumoto et al 2006).

McDermott and Wheater correlated dilutions and effects on migration, adhesion, collagen type four expression and presence of fibronectin of the two commercially available 8-methoxy fluoroquinolones (moxifloxacin and gatifloxacin) on human corneal and conjunctival epithelial cell lines (McDermott and Wheater 2006). Increased toxicity was again correlated with higher drug concentrations. Gatifloxacin was reported to be less toxic than moxifloxacin at all concentrations.

Results of other in vitro studies evaluating, the toxicity of the 8-methoxyfluoroquinolones in human and animal corneal tissues have been mixed. Stern and colleagues used several animal models to compare the cellular effects of gatifloxacin and moxifloxacin on the rate and quality of corneal wound healing. In general, they reported greater corneal epithelial degradation, greater inhibition of collagen IV synthesis, and increased loss of normal structure in the basal lamina (Decemet's membrane) in moxifloxacin treated eyes (Stern et al 2006).

In two studies from the University of Texas Southwestern Medical Center, investigators reported moxifloxacin to be less toxic to the corneal epithelium than all currently available ophthalmic fluoroquinolones (Kovoor et al 2004). Confocal assessment documented maintenance of corneal epithelial integrity and tight junction organization after short term intense dosing with moxifloxacin versus gatifloxacin. Under similar conditions, moxifloxacin induced cell loss and breakdown of tight junctions (Ly et al 2006).

Outcomes of human studies comparing the biocompatibility of moxifloxacin with gatifloxacin and or older fluoroquinolones were also mixed. In 14 healthy volunteers, where $0.5 \%$ moxifloxacin and $0.3 \%$ gatifloxacin drops were randomly administered to the right or left eye at 1 minute intervals for 5 minutes, higher levels of conjunctival injection, discomfort and corneal cell drop out per high power field were reported for the moxifloxacin eyes than for the gatifloxacin eyes. No significant change in pupil size or visual acuity was recorded for the two drugs (Kaufman et al 2006).

Walter reported two cases of severe corneal toxicity after moxifloxacin therapy. Both patients were treated for persisted sterile corneal ulcers that worsened with intense topical dosing with moxifloxacin, but resolved after change in therapy to corticosteroids and gatifloxacin (Walter and Tyler 2006).
Donaldson and coworker reported no differences in visual acuity, tear breakup time or ocular surface integrity in the moxifloxacin treated vs. non treated eyes of healthy subjects dosed 4 times daily for 3 days. Authors concluded that moxifloxacin was safe during the 3 day treatment period that mimicked a prophylactic dosing regimen for patients scheduled for cataract surgery (Donaldson et al 2006).

Durrie and Trattler compared the safety and tolerability of moxifloxacin $0.5 \%$ ophthalmic solution and gatifloxacin $0.3 \%$ ophthalmic solution for treatment and prophylaxis in patients undergoing laser-assisted in situ keratomileusis (LASIK) and laser-assisted subepithelial keratomileusis (LASEK). No differences between the two antibiotics was documented for visual acuity pupil size, SSPK, edema, haze, day and night-time glare halos, clarity of day or night vision, or dry eye symptoms up to 1 week in LASIK patients. Moxifloxacin and gatifloxacin were equivalent in terms of ease of use, speed of recovery, overall vision, and overall comfort for this group of patients. No differences in corneal healing were observed after LASEK surgery (Durrie and Trattler 2005).

Burka et al evaluated the effect of the 8 methoxyfluoroquinolones on epithelial healing following photorefractive keratectomy (PRK). At one month follow up, the moxifloxacin treated eyes had smaller defects and healed faster than patients treated with gatifloxacin (Burka et al 2005). No significant differences in visual outcomes were found in the six month follow up for these patients (Burka et al 2007).

Solomon et al compared penetration and safety of ciprofloxacin, moxifloxacin and gatifloxacin in patients scheduled for cataract surgery. No clinical evidence of epithelial or intraocular toxicity was noted for any of the three drugs (Solomon et al 2005).

In general animal, in vitro, and clinical studies indicate the ocular and systemic safety and tolerability of moxifloxacin for the treatment of ocular infections in children ( 3 days to 17 years) and adults (up to age 93). Reported adverse events including conjunctivitis, keratitis and endophthalmitis have been low (McGee et al 2005; Kleinmann et al 2006).

\section{Emerging resistance issues}

Greater than $94 \%$ of the isolates in the Endophthalmitis Vitrectomy Study were gram positive bacteria (Endophthalmitis Vitrectomy Study Group 1995; Haimann et al 1996; Han et al 1996) . There are increasing reports of grampositive pathogens recovered from post refractive surgery 
infections. One of the anticipated advantages of the new 8-methoxyfluoroquinolones was the increased activity (lower MICs) against resistant gram positive cocci. What has emerged among ocular and nonocular comparative studies is that the gap in improved coverage for resistant gram positive ocular pathogens is less than optimal (Kowalski et al 2003; Mather et al 2004; Miller et al 2006; Moshirfar et al 2006; Oliveira et al 2007).

Pong et al evaluated the in vitro efficacy of moxifloxacin against clinical isolates with varying degrees of resistance to ciprofloxacin. There was a high correlation between increasing ciprofloxacin resistant levels and resistant MICs for both ofloxacin and moxifloxacin for gram positive isolates. The comparative MICs, however, were lower for moxifloxacin than for ofloxacin. In general moxifloxacin MICs were 8- to 32-fold lower for gram-positive isolates and up to four fold lower for susceptible gram negative isolates than for the older fluoroquinolones (Pong et al 1999).

The improved activity of moxifloxacin and gatifloxacin against methicillin resistant $S$. aureus (MRSA) does not translated to in vivo efficacy. No route of drug administration (oral, intravitreal, subconjunctival or topical) has provided concentrations that adequately cover the majority of MRSA with moderate or high level ciprofloxacin resistance.

Kotulus and colleagues documented clinical failure in a subset of 9 patients with MRSA infections treated with moxifloxacin or gatifloxacin. A third of the patients improved with continued treatment with the 8-methoxyfluoroquinolones; however, two thirds needed additional therapeutic intervention and only improved when switched to vancomycin and or other combination therapy. Patients who failed therapy were treated for an average of 4.5 days, while the third with favorable outcomes were treated more long term (18.1 days) (Kotlus et al 2006). Others have also reported treatment failures for patients with MRSA. (Solomon et al 2003; Moshirfar et al 2006; Solomon et al 2007; Woodward and Randleman 2007).

Coagulase-negative staphylococci remain the most frequent pathogen recovered from post cataract endophthalmitis. The consensus is that the origin of pathogens recovered from post cataract infections are seeded from the patient's conjunctiva. Small populations of organisms resistant to the 8 methoxyfluoroquinolones may be presence as part of the resident conjunctiva flora. These may have been "selected" following exposure to older fluoroquinolone. The high concentration and broad spectrum of the fluoroquinolone may disrupt normal conjunctival flora and allow for colonization of more resistant bacterial and or more nonbacterial pathogens.
Mino de Kaspar and colleagues demonstrated a low rate of resistance ( $2 \%$ ) among coagulase negative staphylococci in their study evaluating the normal conjunctiva flora of patients scheduled for anterior segment surgery (Mino de Kaspar et al 2005).

Miller et al documented a high level fluoroquinolone cross resistance among coagulase negative endophthalmitis isolates. Increasing resistance to ciprofloxacin was paralleled by increasing resistance to both moxifloxacin and gatifloxacin. Moxifloxacin provides coverage for 10/38, 26\% and gatifloxacin 13/38, 66\% for the ciprofloxacin-resistant isolates (Miller et al 2006).

\section{Role of moxifloxacin in the management of ocular bacterial infections}

No anti-infective provides ideal coverage for all pathogens for all infected sites. Selection of an effective anti-infective for ophthalmology is dependent on clinical efficacy, background resistance, site of infection, and toxicity.

Moxifloxacin hydrochloride ophthalmic solution $0.5 \%$ is a unique, preservative free, anti-infective which offers elevated tissue concentrations, broad spectrum of activity and a moderate to high rate of clinical success against common ocular pathogens. Declining efficacy against methicillin susceptible and resistant staphylococci and pseudomonas species is a concern. Judicious use is warranted to maintain utility and reduce selection of resistant populations.

\section{References}

Abshire R, Cockrum P, et al. 2004. Topical antibacterial therapy for mycobacterial keratitis: potential for surgical prophylaxis and treatment. Clin Ther, 26:191-6.

Alexandrakis G, Alfonso EC, et al. 2000. Shifting trends in bacterial keratitis in south Florida and emerging resistance to fluoroquinolones. Ophthalmology, 107:1497-502.

Alfonso E, Crider J. 2005. Ophthalmic infections and their anti-infective challenges. Surv Ophthalmol, 50(Suppl 1):S1-6.

Allen GP, Kaatz GW, et al. 2004. In vitro activities of mutant prevention concentration-targeted concentrations of fluoroquinolones against Staphylococcus aureus in a pharmacodynamic model. Int J Antimicrob Agents, 24:150-60.

Appelbaum PC, Hunter PA. 2000. The fluoroquinolone antibacterials: past, present and future perspectives. Int J Antimicrob Agents, 16:5-15.

Ball P, Fernald A, et al. 1998. Therapeutic advances of new fluoroquinolones. Expert Opin Investig Drugs, 7:761-83.

Ball P, Stahlmann R, et al. 2004. Safety profile of oral and intravenous moxifloxacin: cumulative data from clinical trials and postmarketing studies. Clin Ther, 26:940-50.

Blondeau JM. 1999. Expanded activity and utility of the new fluoroquinolones: a review. Clin Ther, 21:3-40; discussion 1-2.

Blondeau JM. 1999. A review of the comparative in-vitro activities of 12 antimicrobial agents, with a focus on five new respiratory quinolones. J Antimicrob Chemother, 43(Suppl B):1-11. 
Burka JM, Bower KS, et al. 2005. The effect of fourth-generation fluoroquinolones gatifloxacin and moxifloxacin on epithelial healing following photorefractive keratectomy. Am J Ophthalmol, 140:83-7.

Burka JM, Bower KS, et al. 2007. The effect of moxifloxacin and gatifloxacin on long-term visual outcomes following photorefractive keratectomy. $J$ Refract Surg, 23:414-7.

Caeiro JP, Iannini PB. 2003. Moxifloxacin (Avelox): a novel fluoroquinolone with a broad spectrum of activity. Expert Rev Anti Infect Ther, 1:363-70.

Cekic O, Batman C, et al. 1999a. Penetration of ofloxacin and ciprofloxacin in aqueous humor after topical administration. Ophthalmic Surg Lasers, 30:465-8.

Cekic O, Batman C, et al. 1999b. Human aqueous and vitreous humour levels of ciprofloxacin following oral and topical administration. Eye, 13:555-8.

Chang Lin JE, Welty D. 2006. Ocular pharmacokinetics of moxifloxacin after topical treatment of animals and humans. Surv Ophthalmol, 51:530; author reply 530-1.

Chaudhry NA, Flynn Jr HW, et al. 1999. Emerging ciprofloxacin-resistant Pseudomonas aeruginosa. Am J Ophthalmol, 128:509-10.

Costello P, Bakri SJ, et al. 2006. Vitreous penetration of topical moxifloxacin and gatifloxacin in humans. Retina, 26:191-5.

Dalhoff A, Schmitz FJ. 2003. In vitro antibacterial activity and pharmacodynamics of new quinolones. Eur J Clin Microbiol Infect Dis, 22:203-21.

Deramo VA, Lai JC, et al. 2006. Acute endophthalmitis in eyes treated prophylactically with gatifloxacin and moxifloxacin. Am JOphthalmol, 142:721-5.

Domagala JM. 1994. Structure-activity and structure-side-effect relationships for the quinolone antibacterials. J Antimicrob Chemother, 33:685-706.

Donaldson KE, Marangon FB, et al. 2006. The effect of moxifloxacin on the normal human cornea. Curr Med Res Opin, 22:2073-80.

Donnenfeld E, Perry HD, et al. 2004. A comparison of the fourth-generation fluoroquinolones gatifloxacin $0.3 \%$ and moxifloxacin $0.5 \%$ in terms of ocular tolerability. Curr Med Res Opin, 20:1753-8.

Donnenfeld ED, Kim T, et al. 2005. ASCRS White Paper: Management of infectious keratitis following laser in situ keratomileusis. J Cataract Refract Surg, 31:2008-11.

Drlica K, Malik M. 2003. Fluoroquinolones: action and resistance. Curr Top Med Chem, 3:249-82.

Durrie DS, Trattler W. 2005. A comparison of therapeutic regimens containing moxifloxacin $0.5 \%$ ophthalmic solution and gatifloxacin $0.3 \%$ ophthalmic solution for surgical prophylaxis in patients undergoing LASIK or LASEK. J Ocul Pharmacol Ther, 21:236-41.

Endophthalmitis Vitrectomy Study Group.1995. Results of the Endophthalmitis Vitrectomy Study. A randomized trial of immediate vitrectomy and of intravenous antibiotics for the treatment of postoperative bacterial endophthalmitis. Endophthalmitis Vitrectomy Study Group. Arch Ophthalmol, 113:1479-96.

Freitas D, Alvarenga L, et al. 2003. An outbreak of Mycobacterium chelonae infection after LASIK. Ophthalmology, 110:276-85.

Fuller JJ, Lott MN, et al. 2007. Vitreal penetration of oral and topical moxifloxacin in humans. Am J Ophthalmol, 143:338-40.

Garcia-Saenz MC, Arias-Puente A, et al. 2001. Human aqueous humor levels of oral ciprofloxacin, levofloxacin, and moxifloxacin. J Cataract Refract Surg, 27:1969-74.

Goldstein MH, Kowalski RP, et al. 1999. Emerging fluoroquinolone resistance in bacterial keratitis:a 5-year review. Ophthalmology, 106:1313-8.

Griggs DJ, Marona H, et al. 2003. Selection of moxifloxacin-resistant Staphylococcus aureus compared with five other fluoroquinolones. $J$ Antimicrob Chemother, 51:1403-7.

Gupta V, Gupta A, et al. 2003. Presumed tubercular serpiginouslike choroiditis: clinical presentations and management. Ophthalmology, 110:1744-9.

Haimann MH, Weiss H, et al. 1996. The Endophthalmitis Vitrectomy Study. Arch Ophthalmol, 114:1025; author reply 1026-7.
Han DP, Wisniewski SR, et al. 1996. Spectrum and susceptibilities of microbiologic isolates in the Endophthalmitis Vitrectomy Study. Am J Ophthalmol, 122:1-17.

Hariprasad SM, Blinder KJ, et al. 2005. Penetration pharmacokinetics of topically administered $0.5 \%$ moxifloxacin ophthalmic solution in human aqueous and vitreous. Arch Ophthalmol, 123:39-44.

Hariprasad SM, Shah GK, et al. 2005. Determination of aqueous and vitreous concentration of moxifloxacin $0.5 \%$ after delivery via a dissolvable corneal collagen shield device. J Cataract Refract Surg, 31:2142-6.

Hariprasad SM, Shah GK, et al. 2006. Vitreous and aqueous penetration of orally administered moxifloxacin in humans. Arch Ophthalmol, 124:178-82.

Harper T, Miller D, et al. 2007. In vitro efficacy and pharmacodynamic indices for antibiotics against coagulase-negative Staphylococcus endophthalmitis isolates. Ophthalmology, 114:871-5.

Hermsen ED, Hovde LB, et al. 2005. Mutant prevention concentrations of ABT-492, levofloxacin, moxifloxacin, and gatifloxacin against three common respiratory pathogens. Antimicrob Agents Chemother, 49:1633-5.

Hofling-Lima AL, de Freitas D, et al. 2005. In vitro activity of fluoroquinolones against Mycobacterium abscessus and Mycobacterium chelonae causing infectious keratitis after LASIK in Brazil. Cornea, 24:730-4.

Hooper DC. 2001a. Emerging mechanisms of fluoroquinolone resistance. Emerg Infect Dis, 7:337-41.

Hooper DC. 2001b. Mechanisms of action of antimicrobials: focus on fluoroquinolones. Clin Infect Dis, 32(Suppl 1):S9-S15.

Hwang DG. 2004. Fluoroquinolone resistance in ophthalmology and the potential role for newer ophthalmic fluoroquinolones. Surv Ophthalmol, 49(Suppl 2):S79-83.

Ince D, Zhang X, et al. 2003. Activity of and resistance to moxifloxacin in Staphylococcus aureus. Antimicrob Agents Chemother, 47:1410-5.

Jacoby GA. 2005. Mechanisms of resistance to quinolones. Clin Infect Dis, 41(Suppl 2):S120-6.

John T, Velotta E. 2005. Nontuberculous (atypical) mycobacterial keratitis after LASIK: current status and clinical implications. Cornea, 24:245-55.

Kampougeris G, Antoniadou A, et al. 2005. Penetration of moxifloxacin into the human aqueous humour after oral administration. Br J Ophthalmol, 89:628-31.

Karp CL, Tuli SS, et al. 2003. Infectious keratitis after LASIK. Ophthalmology, 110:503-10.

Katz HR, Masket S, et al. 2005. Absorption of topical moxifloxacin ophthalmic solution into human aqueous humor. Cornea, 24:955-8.

Kaufman SC, Rusinek C, et al. 2006. Comparison of the biocompatibility of gatifloxacin $0.3 \%$ and moxifloxacin $0.5 \%$. Cornea, 25 (9 Suppl 2): S31-4.

Keating GM, Scott LJ. 2004. Moxifloxacin: a review of its use in the management of bacterial infections. Drugs, 64:2347-77.

Kim DH, Stark WJ, et al. 2005a. Ocular penetration of moxifloxacin $0.5 \%$ and gatifloxacin $0.3 \%$ ophthalmic solutions into the aqueous humor following topical administration prior to routine cataract surgery. Curr Med Res Opin, 21:93-4.

Kim DH, Stark WJ, et al. 2005b. Aqueous penetration and biological activity of moxifloxacin $0.5 \%$ ophthalmic solution and gatifloxacin $0.3 \%$ solution in cataract surgery patients. Ophthalmology, 112:1992-6.

Kleinmann G, Larson S, et al. 2006. Intraocular concentrations of gatifloxacin and moxifloxacin in the anterior chamber via diffusion through the cornea using collagen shields. Cornea, 25:209-13.

Koch HR, Kulus SC, et al. 2005. Corneal penetration of fluoroquinolones: aqueous humor concentrations after topical application of levofloxacin $0.5 \%$ and ofloxacin $0.3 \%$ eyedrops. J Cataract Refract Surg, $31: 1377-85$

Kotlus BS, Wymbs RA, et al. 2006. In vitro activity of fluoroquinolones, vancomycin, and gentamicin against methicillin-resistant Staphylococcus aureus ocular isolates. Am J Ophthalmol, 142:726-9. 
Kovoor TA, Kim AS, et al. 2004. Evaluation of the corneal effects of topical ophthalmic fluoroquinolones using in vivo confocal microscopy. Eye Contact Lens, 30:90-4.

Kowalski RP, Dhaliwal DK, et al. 2003. Gatifloxacin and moxifloxacin:an in vitro susceptibility comparison to levofloxacin, ciprofloxacin, and ofloxacin using bacterial keratitis isolates. Am J Ophthalmol, 136:500-5.

Kowalski RP, Yates KA, et al. 2005. An ophthalmologist's guide to understanding antibiotic susceptibility and minimum inhibitory concentration data. Ophthalmology, 112:1987.

Krasemann C, Meyer J, et al. 2001. Evaluation of the clinical microbiology profile of moxifloxacin. Clin Infect Dis, 32(Suppl 1):S51-63.

Lee SB, Oliver KM, et al. 2005. Fourth-generation fluoroquinolones in the treatment of mycobacterial infectious keratitis after laser-assisted in situ keratomileusis surgery. Can J Ophthalmol, 40:750-3.

Ly LT, Cavanagh HD, et al. 2006. Confocal assessment of the effects of fourth-generation fluoroquinolones on the cornea. Eye Contact Lens, $32: 161-5$.

Mah FS. 2004. Fourth-generation fluoroquinolones: new topical agents in the war on ocular bacterial infections. Curr Opin Ophthalmol, 15:316-20.

Mallari PL, McCarty DJ, et al. 2001. Increased incidence of corneal perforation after topical fluoroquinolone treatment for microbial keratitis. Am J Ophthalmol, 131:131-3.

Marangon FB, Miller D, et al. 2004. Ciprofloxacin and levofloxacin resistance among methicillin-sensitive Staphylococcus aureus isolates from keratitis and conjunctivitis. Am J Ophthalmol, 137:453-8.

Mather R, Karenchak LM, et al. 2002. Fourth generation fluoroquinolones: new weapons in the arsenal of ophthalmic antibiotics. Am JOphthalmol, 133:463-6.

Mather R, Stewart JM, et al. 2004. The effect of cataract surgery on ocular levels of topical moxifloxacin. Am J Ophthalmol, 138:554-9.

Matieli LC, De Freitas D, et al. 2006. Mycobacterium abscessus endophthalmitis: treatment dilemma and review of the literature. Retina, 26:826-9.

Matsumoto S, Way W, et al. 2006. Comparative toxicity of fluoroquinolone antibiotics on corneal cells in vitro. Cornea, 25(9 Suppl 2):S1-7.

McCulley JP, Caudle D, et al. 2006. Fourth-generation fluoroquinolone penetration into the aqueous humor in humans. Ophthalmology, 113:955-9.

McDermott M, Wheater M. 2006. In vitro comparison of the effects of clinically available ophthalmic solutions of gatifloxacin $0.3 \%$ and moxifloxacin $0.5 \%$ on human corneal and conjunctival epithelial cell adhesion and migration and on collagen type IV protein expression. Cornea, 25(9 Suppl 2):S25-S30.

McGee DH, Holt WF, et al. 2005. Safety of moxifloxacin as shown in animal and in vitro studies. Surv Ophthalmol, 50(Suppl 1):S46-54.

Metzler K, Hansen GM, et al. 2004. Comparison of minimal inhibitory and mutant prevention drug concentrations of 4 fluoroquinolones against clinical isolates of methicillin-susceptible and -resistant Staphylococcus aureus. Int J Antimicrob Agents, 24:161-7.

Miller D, Alfonso EC. 2004. Comparative in vitro activity of levofloxacin, ofloxacin, and ciprofloxacin against ocular streptococcal isolates. Cornea, 23:289-93.

Miller D, Flynn PM, et al. 2006. In vitro fluoroquinolone resistance in staphylococcal endophthalmitis isolates. Arch Ophthalmol, 124:479-83.

Miller JJ, Scott IU, et al. 2005. Acute-onset endophthalmitis after cataract surgery (2000-2004): incidence, clinical settings, and visual acuity outcomes after treatment. Am J Ophthalmol, 139:983-7.

Mino de Kaspar H, Koss MJ, et al. 2005. Antibiotic susceptibility of preoperative normal conjunctival bacteria. Am J Ophthalmol, 139:730-3.

Moshirfar M, Meyer JJ, et al. 2007. Fourth-generation fluoroquinoloneresistant mycobacterial keratitis after laser in situ keratomileusis. $J$ Cataract Refract Surg, 33:1978-81.

Moshirfar M, Mirzaian G, et al. 2006. Fourth-generation fluoroquinoloneresistant bacterial keratitis after refractive surgery. $J$ Cataract Refract Surg, 32:515-8.
Munir WM, Rosenfeld SI, et al. 2007. Clinical response of contact lensassociated fungal keratitis to topical fluoroquinolone therapy. Cornea, 26:621-4.

Nielsen JS, Blatt S, et al. 2004. Clinicopathologic case report: scleral buckle associated nontuberculous mycobacterial scleritis. Semin Ophthalmol, 19(3-4):101-4.

O'Brien TP. 2006. Evidence-based review of moxifloxacin. Int Ophthalmol Clin, 46:61-72.

Oliphant CM, Green GM. 2002. Quinolones: a comprehensive review. Am Fam Physician, 65:455-64.

Oliveira AD, D'Azevedo PA, et al. 2007. In vitro activity of fluoroquinolones against ocular bacterial isolates in Sao Paulo, Brazil. Cornea, 26:194-8.

Ong-Tone L. 2007. Aqueous humor penetration of gatifloxacin and moxifloxacin eyedrops given by different methods before cataract surgery. J Cataract Refract Surg, 33:59-62.

Ozdek SC, Miller D, et al. 2006. In vitro antifungal activity of the fourth generation fluoroquinolones against Candida isolates from human ocular infections. Ocul Immunol Inflamm, 14:347-51.

Peterson LR. 2001. Quinolone molecular structure-activity relationships: what we have learned about improving antimicrobial activity. Clin Infect Dis, 33(Suppl 3):S180-6.

Pong A, Thomson KS, et al. 1999. Activity of moxifloxacin against pathogens with decreased susceptibility to ciprofloxacin. J Antimicrob Chemother, 44:621-7.

Robertson SM, Curtis MA, et al. 2005. Ocular pharmacokinetics of moxifloxacin after topical treatment of animals and humans. Surv Ophthalmol, 50(Suppl 1):S32-45.

Robicsek A, Jacoby GA, et al. 2006. The worldwide emergence of plasmidmediated quinolone resistance. Lancet Infect Dis, 6:629-40.

Robicsek A, Strahilevitz J, et al. 2006. Fluoroquinolone-modifying enzyme: a new adaptation of a common aminoglycoside acetyltransferase. Nat Med, 12:83-8.

Saravolatz LD, Leggett J. 2003. Gatifloxacin, gemifloxacin, and moxifloxacin:the role of 3 newer fluoroquinolones. Clin Infect Dis, 37:1210-5.

Schlech BA, Alfonso E. 2005. Overview of the potency of moxifloxacin ophthalmic solution 0.5\% (VIGAMOX). Surv Ophthalmol, 50(Suppl 1):S7-15.

Sharma S, KDY, et al. 1999. Trends in antibiotic resistance of corneal pathogens: Part I. An Analysis of commonly used antibiotics. Indian J Ophthalmol, 47:95-100.

Smith A, Pennefather PM, et al. 2001. Fluoroquinolones: place in ocular therapy. Drugs, 61:747-61.

Smith HJ, Walters M, et al. 2004. Mutant prevention concentrations for single-step fluoroquinolone-resistant mutants of wild-type, efflux-positive, or ParC or GyrA mutation-containing Streptococcus pneumoniae isolates. Antimicrob Agents Chemother, 48:3954-8.

Solomon R, Donnenfeld ED, et al. 2003. Bilateral methicillin-resistant staphylococcus aureus keratitis in a medical resident following an uneventful bilateral photorefractive keratectomy. Eye Contact Lens, 29:187-9.

Solomon R, Donnenfeld ED, et al. 2007. Methicillin-resistant Staphylococcus aureus infectious keratitis following refractive surgery. Am J Ophthalmol, 143:629-34.

Solomon R, Donnenfeld ED, et al. 2005. Penetration of topically applied gatifloxacin $0.3 \%$, moxifloxacin $0.5 \%$, and ciprofloxacin $0.3 \%$ into the aqueous humor. Ophthalmology, 112:466-9.

Spencer TS, Teske MP, et al. 2005. Postcataract endophthalmitis caused by Mycobacterium goodii. J Cataract Refract Surg, 31:1252-3.

Stern ME, Gao J, et al. 2006. Effects of fourth-generation fluoroquinolones on the ocular surface, epithelium, and wound healing. Cornea, 25(9 Suppl 2):S12-S24.

Stroman DW, Dajes JJ, et al. 2005. In vitro and in vivo potency of moxifloxacin and moxifloxacin ophthalmic solution $0.5 \%$, a new topical fluoroquinolone. Surv Ophthalmol, 50(Suppl 1):S16-31.

Takei M, Fukuda H, et al. 2001. Target preference of 15 quinolones against Staphylococcus aureus, based on antibacterial activities and target inhibition. Antimicrob Agents Chemother, 45:3544-7. 
Van Bambeke F, Michot JM, et al. 2005. Quinolones in 2005: an update. Clin Microbiol Infect, 11:256-80.

Vedantham V, Lalitha P, et al. 2006. Vitreous and aqueous penetration of orally administered moxifloxacin in humans. Eye, 20:1273-8.

Vigamox. 2004. [package insert]. Fort Worth, TX, Alcon Laboratories.

Walter K, Tyler ME. 2006. Severe corneal toxicity after topical fluoroquinolone therapy: report of two cases. Cornea, 25:855-7.

Walter S, Kuchenbecker J, et al. 2007. Concentration of moxifloxacin in serum and human aqueous humor following a single $400 \mathrm{mg}$ oral dose. $J$ Cataract Refract Surg, 33:553-5.

Wilhelmus KR. 2003. Evaluation and prediction of fluoroquinolone pharmacodynamics in bacterial keratitis. J Ocul Pharmacol Ther,19:493-9.

Wilhelmus KR. 2003. Nontuberculous mycobacterial endophthalmitis. Arch Ophthalmol, 121:1663.

Wilhelmus KR, Abshire RL, et al. 2003. Influence of fluoroquinolone susceptibility on the therapeutic response of fluoroquinolone-treated bacterial keratitis. Arch Ophthalmol, 121:1229-33.
Winthrop KL, Steinberg EB, et al. 2003. Epidemic and sporadic cases of nontuberculous mycobacterial keratitis associated with laser in situ keratomileusis. Am J Ophthalmol, 135:223-4.

Wise R. 2003. Maximizing efficacy and reducing the emergence of resistance. J Antimicrob Chemother, 51(Suppl 1):7-42.

Woodward M, Randleman JB. 2007. Bilateral methicillin-resistant Staphylococcus aureus keratitis after photorefractive keratectomy. J Cataract Refract Surg, 33:316-9.

Zhanel GG, Ennis K, et al. 2002. A critical review of the fluoroquinolones: focus on respiratory infections. Drugs, 62:13-59.

Zhanel GG, Fontaine S, et al. 2006. A review of new fluoroquinolones: focus on their use in respiratory tract infections. Treat Respir Med, 5:437-65.

Zhanel GG, Noreddin AM. 2001. Pharmacokinetics and pharmacodynamics of the new fluoroquinolones: focus on respiratory infections. Curr Opin Pharmacol, 1:459-63. 
